
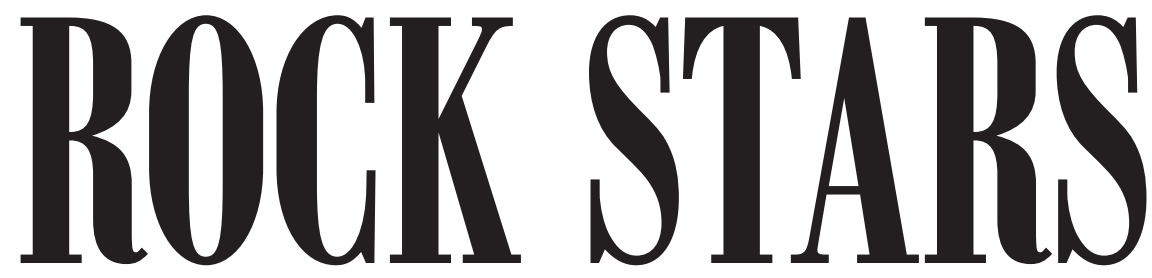

\section{Raymond Cecil \\ Moore: A Great 20th Century \\ Geological Synthesizer}

\author{
Daniel F. Merriam, Kansas Geological \\ Survey, University of Kansas, Lawrence, \\ Kansas 66047, USA
}

R.C. Moore (1892-1974), administrator, researcher, teacher, world-class stratigrapher and paleontologist, linguist, and artist — a man of many talents—was born 20 February 1892 in Roslyn, Washington, in the Wenatchee Mountains. The eldest of four children born to Bernard Harding Moore, a Baptist minister of Irish descent, and Winifred Denney of Elk Falls, Kansas, Moore was educated at Denison University (Ohio) and granted an A.B. degree with honors in the classics in 1913. At Denison, he was introduced to geology by the learned geologist Frank Carney and was such a good student that he was hired to teach geology his senior year while Carney was on leave.

Moore continued his studies in geology at the University of Chicago and was awarded a doctorate (summa cum laude) three years later for his dissertation on the Early Mississippian formations of Missouri, supervised by Stuart Weller. His education at Chicago included instruction from the giants of the day-Weller, Thomas C. Chamberlain, Samuel W. Williston, and Rollin D. Salisbury. On completion of his studies at Chicago in 1916, he was hired as an assistant professor of geology at the University of Kansas and also state geologist and director of the State Geological Survey of Kansas. Moore replaced W.H.

Twenhofel, who left for the University of Wisconsin after having been state geologist for just one year. Twenhofel had replaced the retiring Erasmus "Daddy" Haworth, although Haworth continued
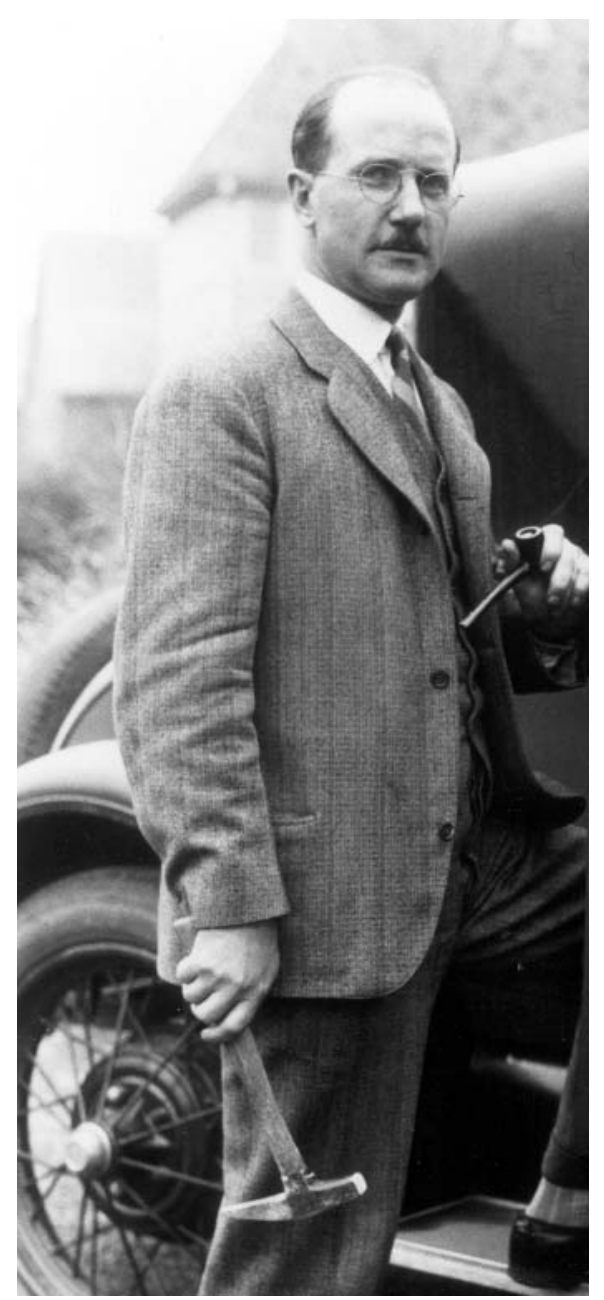

R.C. Moore dressed for fieldwork in the early 1930s.

as chairman of the department (Merriam, 1975, 2002; Maples and Buchanan, 1989).

Almost immediately, Moore turned his attention to refining the PermoPennsylvanian stratigraphy of the Midcontinent. His attention to detail allowed him to correlate individual beds as thin as $5 \mathrm{~cm}$ from Nebraska southward to Oklahoma; his measured sections are impeccable. From this detail, he was able to formulate his ideas on cyclic sedimentation and "genetic stratigraphy," as he phrased it, a forerunner of what we know today as sequence stratigraphy. He was particularly interested in the succession of depositional environments and he defined them by unique fossil assemblages. Many of these studies were the basis for a series of Kansas Geological Society field conferences in the 1930s, a summary publication on the Pennsylvanian of Kansas in 1936, and the revised and updated geological map of Kansas, published in 1937 with co-author Kenneth K. Landes. His flair for organization and technicalities was evident with these activities as he coerced and cajoled his colleagues into a uniform stratigraphic code for the Midcontinent. (He later showed these same abilities as chairman of the U.S. Committee on Stratigraphic Nomenclature and the Committee on Zoological Nomenclature.)

Moore envisioned individual cyclothems to consist of genetically related units, that is, a succession of sediment types deposited in a shallow epicontinental sea by a single advance and retreat of the sea. He extended the original concepts of J.A. Udden and J.M. Weller on cyclothems to a bundle of related cyclothems (usually five, each represented by the culminating marine limestone separated by thick nonmarine clastics), which he termed a "megacyclothem." Moore noted testily:

The notion that any geologist seriously challenges the existence of many orderly successions of lithologically (and paleontologically) differing sorts of rock layers in the Pennsylvanian-Permian part of the geologic column of Kansas and other regions seems preposterous, unless excuse is made for such a geologist that he is grossly uninformed of field facts. (Moore and Merriam, 1959, p. 46)

Moore used a rather elaborate classification for the genetic units based on a decimal-type system. He believed this classification was necessary because the genetic units (cyclothems) could not be mapped easily and there would be no ambiguity with rock units using such a dual classification. He envisioned a similar scheme for his megacyclothems, but neither scheme was adopted by other field geologists.

Using his extensive background in Permo-Pennsylvanian stratigraphy of the Midcontinent and Kansas in particular, Moore took an integral part in the discussions of the 1940s concerning rock cycles and facies as did L.L. Sloss, W.C. Krumbein, E.C. Dapples, H.R. Wanless, and J.M. Weller. In 1949, Sloss, 
Krumbein, and Dapples defined sequence in its modern sense as the rock sequence or operational unit between operational datum horizons (unconformities) in the Paleozoic of the midAmerican craton and named the intervals. These sequences correspond approximately timewise (in a stratigraphic sense) to Joseph Barrell's major depositional cycle (1917), M.K. Elias' grand cycle (1936), and P.D. Krynine's tectonic cycle (1941). Moore suggested the term "magnacycle" to describe these large cycles, but it was never accepted, and sequence prevailed.

Moore entered the arena on facies in 1949 with his defining paper "Meaning of Facies" as an introduction to the Geological Society of America's Memoir 39. In this paper, he sought to clarify the use of terms and classification for the description of variations that characterize cyclic sediments, especially in PermoPennsylvanian units of the Midcontinent.
He later pioneered the use of ecological communities (ecosystems) to help understand cyclothems. Based on his extensive field work in the Kansas PermoPennsylvanian section, he identified and described 20 representative ecologic communities (Moore, 1964). He concluded that (1) many different paleobiotopes could be distinguished, and (2) these communities could be used to test the paleoecological interpretation of cyclically arranged sedimentary deposits. This was Moore's last contribution to the subject, albeit an important one.

Moore had a steel-trap mind and total recall so that he never forgot a person, detail, or place. He could identify a person from his past with complete confidence, recall an event, or locate an outcrop measured decades before; he had an uncanny sense of time and place. The thoroughness and orderliness of his legalistic mind with which he outlined the stratigraphy of Kansas is obvious, as his

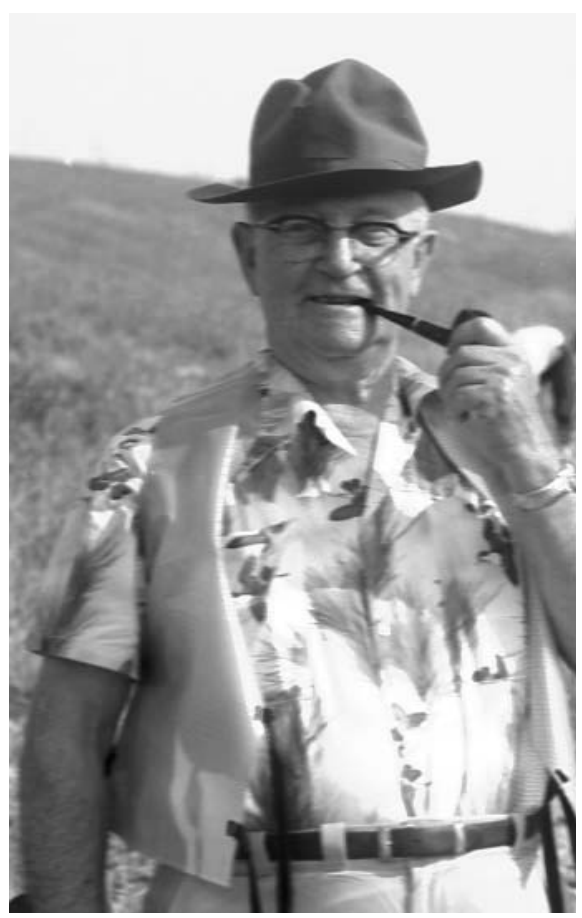

R.C. Moore in the field in 1962.

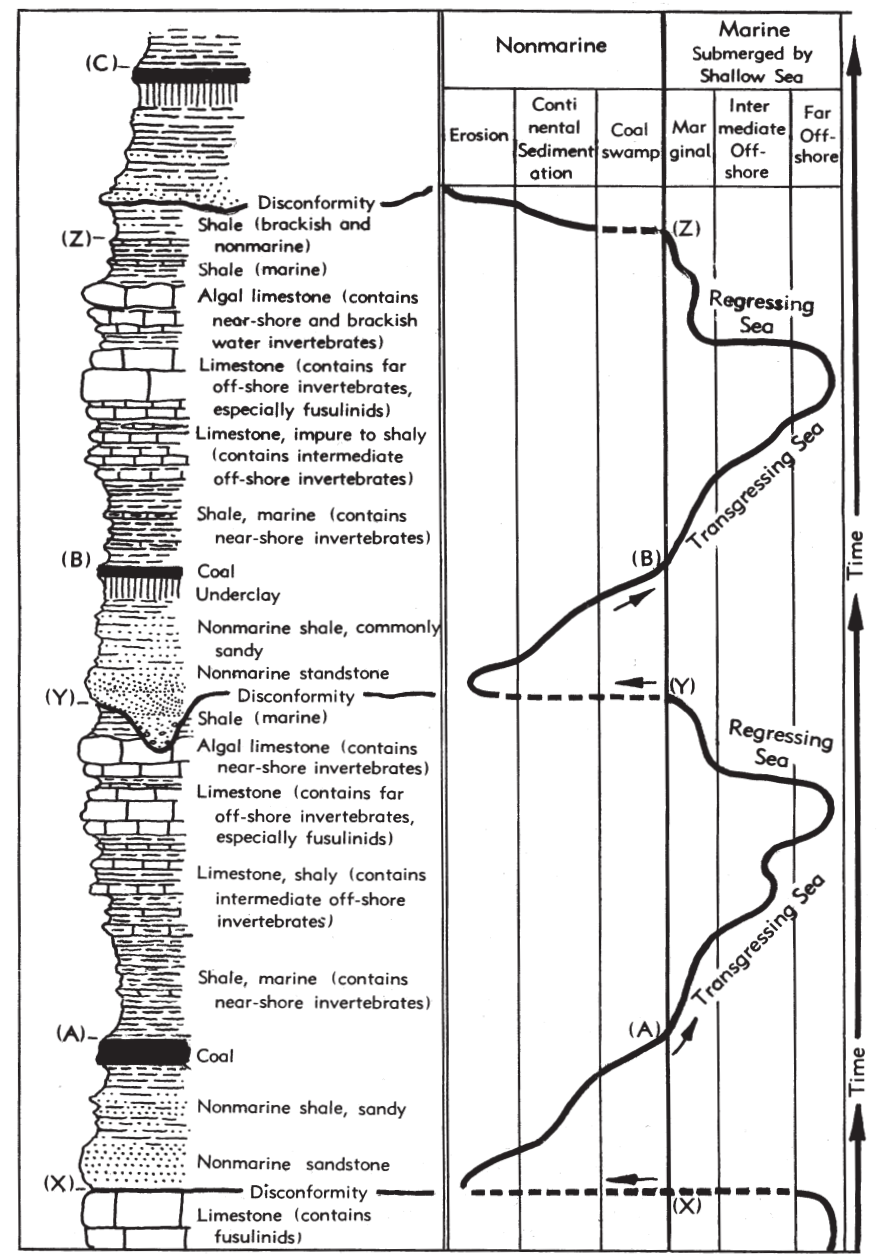

Advancing sea at Lawrence, Kansas, in Pennsylvanian time (sketch by R.C. Moore). classification stands today — essentially unchanged—as he proposed it. As the stratigraphic and sedimentological framework took form, he focused his attention on invertebrate paleontology. He showed his versatility in the subject by working with flora as well as fauna, particularly with corals, crinoids, gastropods, and bryozoans. His paleontological work culminated in the classic and yet-used textbook Invertebrate Fossils published in 1952 with co-authors C.G. Lalicker and A.G. Fischer. His lasting contribution was in the conception, organization, and implementation of the Treatise on Invertebrate Paleontology. This gigantic undertaking was envisioned by Moore as early as 1948, with the first volume appearing in 1953. This ongoing synthesis rivals in scope Alexander von Humboldt's nineteenth century Cosmos, Carl Linnaeus' eighteenth century Systema Naturae, and Count de Buffon's Histoire Naturelle.

The list of services to Moore's chosen profession is almost endless as are his contributions to the Kansas Geological Survey, University of Kansas, and State of Kansas. He served as state geologist and director of the State Geological Survey of Kansas from 1916 to 1954 and as principal geologist thereafter. He was chairman of the Department of Geology on three separate occasions (1920-1939, 1940-1941, 1952-1954) and was named one of the first four distinguished professors of the university in 1958; he was accorded emeritus status in 1962.

Of the many honors and awards he received during his career, Moore was most proud that in 1973, the new Kansas Geological Survey building on (KU's) Campus West was named in his honor. He was recognized by many organizations, including his alma mater (Denison), the Philadelphia Academy of Natural Sciences, American Association of Petroleum Geologists, Paleontological Society, Academie Royale de Belgique, Geological Society of London, National Academy of 
Sciences, and SEPM (Society for Sedimentary Geology). He served as an officer or on committees for many of these organizations. Two honors that he would have cherished but that eluded him were election to the National Academy of Sciences and the Penrose Medal from the Geological Society of America.

"Ol' Professor Ray Moore" was immortalized in a Pogo comic strip telling about the mythical bird, Jayhawkornis kansasensis. He lived to read his obituary after an incident on the Colorado River in which the famous 1923 Birdseye River mapping expedition was assumed lost after a flash flood. At 51, he volunteered for active military service in WWII and later served as a consultant to General Douglas MacArthur in Japan. He was fluent in French, German, and Dutch and conversant in several other languages; he was also a talented artist. Without doubt, he could have been successful in any field he chose.

Moore was an ambitious person with definite objectives. Outwardly, he was a cold and demanding person. In his younger days, he treated colleagues with indifference, and he had zero tolerance for incompetence. He was astringent and, as a result, perhaps unknowingly, made many professional enemies. This gruff treatment of friends and colleagues alike was, in his opinion, for their own good and was meant to correct their deficiencies. W.W. Hambleton described Moore in these words: "He possessed a large ego or, perhaps more appropriately, was comfortable in his knowl- edge of his own worth." But Moore did have a wily sense of humor, and as an example, named the Aarde Shale in 1932 for a farm in east-central Kansas just to assure that his proposed name was the first term in the stratigraphic lexicon-and it is. Inwardly, he was a good and caring person but, unfortunately, he did not know how to show affection. He mellowed considerably in his later years and to some, at least, he was a valued friend and ally.

Although his personal life remained private, it probably was not a very happy one, and family contacts were minimal. He was married twice and had a daughter by his first wife. He died in Lawrence, Kansas, on 16 April 1974 at the age of 82 while editing his beloved Treatise. He willed his estate to the University of Kansas and the Geological Society of America for continued support of the Treatise-his lasting legacy. Raymond Cecil Moore was the consummate and committed scholar.

\section{References Cited}

Maples, C.G., and Buchanan, R.C., 1989, Raymond Ceci Moore (1892-1974): Memorial and bibliography: Lawrence, Kansas, Journal of Paleontology, v. 63, 29 p.

Merriam, D.F., 1975, Obituary for Raymond Cecil Moore: Geological Society of London, Annual Report 1974, p. $42-43$

Merriam, D.F., 2002, Exploring for petroleum in the Flatlands: History of oil and gas exploration in Kansas: Oil-Industry History, v. 3, no. 1, p. 56-71.

Moore, R.C., 1964, Paleoecological aspects of Kansas Pennsylvanian and Permian cyclothems, in Merriam, D.F., ed., Symposium on Cyclic Sedimentation: Lawrence, Kansas, Kansas Geological Survey Bulletin 169, p. 285-380.

Moore, R.C., and Merriam, D.F., 1959, Kansas field conference, 1959: Kansas Geological Survey Guidebook, 55 p.

"Rock Stars" is produced by the GSA History of Geology Division. Editorial Committee: Robert Dott, Robert Ginsburg (editor of this profile), Gerard Middleton, Peter von Bitter, and E.L. (Jerry) Winterer. 